\title{
Implementasi Manajemen Kelas Di Sekolah Dasar Negeri Kecamatan Bacukiki Kota Parepare
}

\author{
Rasmi Djabba \\ Program Studi PGSD Fakultas Ilmu Pendidikan Universitas Negeri Makassar \\ Rasmi.djabba@unm.ac.id
}

\begin{abstract}
This research is descriptive quantitative research to the implementation of the management class at a public elementary school districts Bacukiki Parepare. The purpose of this study was to obtain an overview of the implementation of the management class held by the teacher to the student and determine the factors that become an obstacle in the implementation of classroom management in Bacukiki Elementary School District of City of Parepare. The result showed that the ability of classroom management sub-district public primary school teachers Bacukiki Parepare in the middle category. Overall, teachers who have a grade-level management capabilities over many frequencies teachers who is in the category of moderate to very high category is the category with the very low to low category. The constraints experienced in the classroom management is lack of availability of adequate learning facilities such as completeness of the tools of learning science, social studies, and still lack of supporting books and reference in the library that can not optimize acceleration school purposes, the number of students is too much on almost in every classroom, and other barriers is very limited available of funds.
\end{abstract}

Keyword: implementation of classroom management

\section{PENDAHULUAN}

Pendidikan Dasar sebagai jenjang pendidikan formal yang terikat dalam suatu Sistem Pendidikan Nasional yang terarah dan diarahkan kepada mencerdaskan kehidupan bangsa dan mengembangkan manusia Indonesia seutuhnya merupakan suatu mata rantai yang saling memberikan pengaruh yang cukup besar terhadap kualitas sumber daya manusia. Oleh karena itu, dalam proses belajar mengajar guru dituntut untuk menguasai manajemen kelas.

Manajemen kelas yang baik memungkinkan gurumelaksanakan tugasnya dengan baik, karena kelas dapat terhindar dari berbagai masalah dan memungkinkan guru mengembangkan segala yang diinginkannya. Dengan demikian, guru dapat membangun hubungan yang harmonis dengan siswa sebagai warga belajar.

Keterampilan manajemen kelas menduduki posisi primer dalam menentukan keberhasilan pross pembelajaran yang diukur dan efektifitas proses belajar siswa atau peringkat yang dicapainya. Temuan penelitian Good \& Brophy(dalam Danin,2002:190) menunjukkan bahwa guru yang mendekati manajemen kelas sebagai proses pemapaman dan pemeliharaan lingkungan belajar efektif cenderung lebih sukses dari pada guru-guru yang memerankan guru sebagai figur otoritas atau penegak disiplin belaka.

Kondisi yang dipaparkan adalah kondisi yang ideal, namun dari pengamatan awal peneliti menemukan bahwa masih ada guru yang belum memanajemeni kelas dengan baik.Hal ini menyebabkan proses belajar mengajar belum optimal.Hal ini dikuatkan dengan hasil pemantauan pengawas sekolah tentang mutu hasil belajar belum memberikan hasil yang menggembirakan,terbukti hasil perolehan nilai ujian akhir sekolah (UAS) 2011/2012 pada jenjang pendidikan dasar dikecamatan Bacukiki Kota Parepare masih rendah.Menurut pengamatan peneliti, penyebab kegagalan tersebut adalah guru tidak memanajemen kelas dengan baik dalam kegiatan proses belajar mengajar sehingga hasilnya belum optimal.

Manajemen kelas terdiri dari dua kata,yaitu manajemen dan kelas.Manajemen berasal dari bahasa inggeris "management", yang berarti pengelolaan.Sedangkan yang dimaksud kelas adalah sekolompok siswa yang ada ada waktu yang sama menerima pelajaran yang sama dari guru yang sama pula.Dengan demikian, maksud manajemen kelas adalah mengacu kepada penciptaan suasana atau kondisi kelas 
yang memungkinkan siswa dalam kelas tersebut dapat belajar efektif.

Manajemen kelas mengarah pada peran guru untuk menata pembelajaran. Menurut Soemarto(1990), manajemen kelas akan lebih efektif jika ada faktor-faktor pendukung, yaitu (21) pengelolaan kelas,meliputi penataan ruang kelas,waktu pembelajaran, dan sumber belajar. (2) Pengelolaan siswa, mencakup interaksi siswa dan penerapan disiplin.

Manajemen kelas yang dilakukan oleh guru memiliki tujuan untuk meningkatkan mutu pembelajaran, dan jika tercapainya tujuan pembelajaran maka karakter kelas yang dihasilkan melalui proses pengelolaan kelas yang baik pula. Untuk mewujudkan manajemen kelas yang baik, ada beberapa pendekatan yang dapat dilakukan . pendekatan tersebut Thomas menurut Gordon (dalam Faturrohman, 2007) adalah pendekatan kekuasaan, pendekatan kebebasan, pendekatan keseimbangan peran, pendekatan pengajaran dan pendekatan kombinasi.

Dalam melaksanakan manajemen kelas, perlu adanya prosedur yang harus dilakukan. Adapun prosedur dalam manajemen kelas adalah prosedur dimensi pencegahan dan prosedur dimensi penyembuhan. Dimensi pencegahan adalah tindakan yang dilakukan sebelum munculnya tingkah laku yang menyimpang yang mengganggu kondisi optimal berlangsungnya pembelajaran. Prosedur yang dilakukan pada dimensi pencegahan adalah peningkatan kesadaran diri sebagai guru, peningkatan kesadaran diri siswa, sikap tulus dari guru, menciptakan kontak sosial, mengenal dan menemukan alternatif pengelolaan.

Sedangkan dimensi penyembuhan adalah tindakan yang dilakukan setelah munculnya tingkah laku yang menyimpang. Adapun prodesur dalam dimensi penyembuhan adalah mengidentifikasikan masalah, menganalisis masalah, menilai alternatif-alternatif pemecahan, dan mendapatkan balikan.

Manajemen kelas merupakan pangkal kegiatan yang dapat berdimensi preventif dan kuratif, sehingga perencanaan prosedur manajemen kelas kearah preventif dan kuratif semuanya bermuara pada tujuan yang diharapkan. Tujuan itu adalah terciptanya kondisi serta mempertahankan kondisi optimal yang mendukung terlaksananya proses belajar mengajar.

Penyusunan rancangan prosedur manajemen kelas dipengaruhi oleh beberapa faktor antara lain: (1) pemahaman terhadap arti tujuan dan hakikat manajemen kelas, (2) pemahamn terhadap hakikat peserta didik yang sedang dihadapi, (3) pemahaman terhadap betuk penyimpangan, (4) pemahaman terhadap pendekatan dalam manajemen kelas dan, (5) pemilikan pengetahuan dan keterampilan dalam membuat rancangan prosedur manajemen kelas.

Berdasarkan uraian tersebut, maka dipandang perlu melakukan penelitian lebih mendalam lagi berkaitan dengan Implementasi manajemen kelas. Oleh karena itu, dilakukan penelitian dengan judul "Implementasi Manajemen Kelas di Sekolah Dasar Negeri Kecamatan Bacukiki Kota Parepare".

\section{METODE PENELITIAN}

Jenis penelitian ini mengenakan pendekatan deskriptif kuantitatif. Lokasi penelitian ini dilaksanakan di sekolah dasar negeri kecamatan Bacukiki Kota Parepare. Variabel yang diteliti dalam peneiltian ini adalah implementasi manajemen kelas yang dilaksakana oleh guru terhadap sisiwa dan hambaran-hambatan yang dialami guru di sekolah dasar negeri Kecamatan Bacukiki Kota Parepare.

Populasi dalam peneilitian ini adalah seluruh sekolah dasar yang adal di kecamatan bacukiki kota Parepare yang berjumlah 296 orang guru sekolah dasar pada 4 wilayah yaitu Wilayah 1 sebanyak 11 sekolah dasar, wilayah 2 sebanyak 11 sekolah dasar, wilayah 3 sebanyak 8 sekolah dasar dan wilayah 4 sebanyak 6 sekolah dasar. Setiap wilayah dipilih 2 sekolah dasar sebagai sampel penelitian. Setiap sekolah 6 orang guru. Dengan demikian dalam penelitian ini terdapat 48 orang guru sebagai informan yang berasal dari empat wilayah yang berbeda.

Teknik pengumpulan data yang digunakan dalam penelitian ini adalah kuesioner dan observasi. Teknik analisis data yang digunakan dalam penelitian ini adalah statistik deskriptif dalam bentuk tabel persentase. Menurut Arikunto (1996:243) data yang telah terkumpul dapat diklasifikasikan menjadi dua kelompok data yaitu data kualitatif dan data kuantitatif.

Data yang bersifat kualitatif dapat digambarkan dengan kata-kata menurut kategori tertentu, data kuantitatif dalam penelitian ini dilakukan dengan analisis deskriptif dengan analisis persentase, rata-rata, modus dan median dengan analisis sederhana. 


\section{HASIL \& PEMBAHASAN}

a. Penataan Ruang Kelas

Hasil perhitungan statistik deskriptif yang didasarkan frekuensi pilihan responden terhadap kategori jawaban diperoleh nilai ratarata (mean) sebesar 24,38. Angka berada pada kategori sedang, menunjukkan kemampuan guru dalam menata ruang kelas di sekolah dasar negeri Kecamatan Bacukiki Kota Parepare. Modus atau nilai yang paling sering muncul sebesar 28 mengindikasikan frekuensi jawaban responden yang terbesar. Median sebagai ukuran yang membagi 2 kecenderungan jawaban responden diperoleh nilai 20 dan berada pada kategori sedang.

\section{b. Interaksi Guru-siswa}

Hasil perhitungan statistik deskriptif yang didasarkan frekuensi pilihan responden terhadap kategori jawaban diperoleh nilai ratarata (mean) sebesar 15,23. Angka ini berada pada kategori tinggi menunjukkan interaksi guru-siswa di SD Negeri Kecamatan Bacukiki Kota Parepare selama ini telah diupayakan secara optimal. Modus atau nilai yang paling sering muncul sebesar 18 mengindikasikan frekuensi jawaban responden yang terbesar. Median sebagai ukuran yang membagi 2 kecenderungan jawaban responden diperoleh nilai 23 dan berada pada kategori tinggi.

\section{c. Pengaturan Waktu pembelajaran}

Hasil perhitungan statistik deskriptif yang didasarkan frekuensi pilihan responden terhadap kategori jawaban diperoleh nilai ratarata (mean) sebesar 30,77 angka ini berada pada kategori sedang pada pengaturan waktu pembelajaran di Sekolah Dasar Negeri Kecamatan Bacukiki Kota Parepare selama ini telah diupayakan secara optimal. Modus atau nilai yang paling sering muncul sebesar 29 mengindikasikan frekuensi jawaban responden yang terbesar. Median sebagai ukuran yang membagi 2 kecenderungan jawaban responden diperoleh nilai 35 dan berada pada kategori sedang.

\section{d. Pengaturan Sumber Belajar}

Hasil perhitungan statistikyang didasarkan pada frekuensi pilihan responden terhadap kategori jawaban diperoleh nilai ratarata (mean) sebesar 21,99. Jika dilakukan pembulatan angka berada pada kategori sedang menunjukkan tingginya kemampuan guru dalam mengatur sumber belajar di Sekolah Dasar Negeri Kecamatan Bacukiki Kota Parepare telah diupayakan secara optimal.
Modus atau nilai yang paling sering muncul sebesar 17 mengindikasikan frekuensi jawaban responden yang terbesar. Median sebagai ukuran yang membagi 2 kecenderungan jawaban responden diperoleh nilai 24,5 dan berada pada kategori sedang.

\section{e. Tata Tertib}

Hasil perhitungan statistik deskriptif yang didasarkan pada frekuensi pilihan responden terhadap kategori jawaban diperoleh nilai ratarata (mean) sebesar 16,61 angka ini berada pada kategori sedang menunjukkan perhatian terhadap tata tertib di Sekolah Dasar Negeri Kecamatan Bacukiki Kota Parepare selama ini telah diupayakan secara optimal. Modus atau nilai yang paling sering muncul sebesar 17,5 mengindikasikan frekuensi jawaban responden yang terbesar. Median sebagai ukuran yang membagi 2 kecenderungan jawaban responden diperoleh nilai 15 dan berada pada kategori sedang.

\section{f. Pemberian Pujian}

Hasil perhitungan statistik deskriptif yang didasarkan frekuensi pilihan responden terhadap kategori jawaban diperoleh nilai ratarata (mean) sebesar 18,82. Jika dilakukan pembulatan, angka berada pada kategori sedang menunjukkan pemberian pujian di Sekolah Dasar Negeri Kecamatan Bacukiki Kota Parepare diupayakan secara optimal. Modus atau nilai yang paling sering muncul sebesar 21 mengindikasikan frekuensi jawaban responden yang terbesar. Median sebagai ukuran yang membagi 2 kecenderungan jawaban responden diperoleh nilai 19 dan berada pada kategori sedang.

\section{g. Pemberian sanksi melalui peringatan/ hukuman}

Hasil perhitungan statistik deskriptif yang didasarkan frekuensi pilihan responden terhadap kategori jawaban diperoleh nilai ratarata (mean) sebesar 12,97 angka ini berada pada kategori sedang menunjukkan pemberian sanksi/peringatan di Sekolah Dasar Negeri Kecamatan Bacukiki Kota Parepare selama ini telah diupayakan secara optimal. Modus atau nilai yang paling sering muncul adalah 14 mengindikasikan frekuensi jawaban responden yang terbesar. Median sebagai ukuran yang membagi 2 kecenderungan jawaban responden diperoleh nilai 23 dan berada pada kategori sedang.

Berdasarkan hasil observasi dan wawancara terhadap guru-guru di sekolah dasar yang 
dijadikan responden, diketahui bahwa faktor yang menjadi penghambat dalam implementasi manajemen kelas yang dialami guru dalam mengajar adalah kurang tersedianya fasilitas pembelajaran yang memadai seperti kelengkapan alat-alat pembelajaran IPA, IPS serta masih minimnya buku-buku penunjang maupun referensi di perpustakaan yang tidak dapat mengoptimalkan percepatan tujuan sekolah, jumlah murid yang terlalu banyak pada hampir di setiap ruang kelas, dan hambatan lain adalah kesediaan dana yang terbatas.

Keterbatasan dana tersebut menyebabkan dana tersebut menyebabkan sejumlah kegiatan yang seharusnya terlaksana dengan baik, tidak dapat terealisasi secara optimal, bahkan masih banyak kegiatan yang akan direncanakan harus dibatalkan.

\section{Pembahasan}

Ruangan tempat belajar harus memungkinkan siswa dapat bergerak leluasa, tidak berdesak-desakan, sehingga tidak saling mengganggu satu sama lainnya pada saat terjadi aktivitas pembelajaran. Pengaturan tempat duduk sebaiknya menarik minat siswa dan disesuaikan dengan mata pelajaran yang akan dipelajari. Selain itu, pengaturan juga harus melihat jumlah siswa yang ada di dalam kelas tersebut.

Aktivitas proses belajar mengajar tergantung pada guru dan menuntut sangat banyak perhatian dari guru. Menurut sardiman (2005) bagaimanapun baiknya bahan pelajaran yang diberikan, bahaimanapun sempurnanya metode yang digunakan, namun jika hubungan/interaksi guru-siswa menunjukkan hubungan yang tidak harmonis maka dapat menciptakan suatu hasil yang tidak diinginkan. Pengaturan waktu pembelajaran adalah sangat berpengaruh terhadap pembelajaran. Menurut Entang dan Joni (1983), teknik yang dapat membantu pemeliharaan disiplin kelas dalam mengajar adalah (1) tepat waktu dan mulailah pelajaran sesegera mungkin, (2) siapkan rencana pelajaran dan informasikan kepada siswa apa, kapan, dan dimana aktivitas akan dikerjakan (3) tidak mengancam dan menantang para siswa (4) jagalah dan kontrol suara guru.

Pengaturan sumber belajar pada sekolah dasar masih dalam tingkatan sedang, karena masih ada sebagian sekolah yang belum memanfaatkan buku-buku wajib. Menurut Sadiman (1981) bahwa segala macam sumber yang ada diluar diri seseorang dan yang memungkinkan/memudahkan terjadinya proses belajar disebut sumber belajar.

Peraturan/tata tertib kelas yang baik merupakan salah satu unsur penting dalam menciptakan disiplin kelas, tetapi dengan peraturan/tata tertib kelas yang baik tidaklah menjadi jaminan bahwa disiplin kelas dapat terwujud dengan sendirinya, dalam hal ini guru memainkan peran kunci bagi terlaksananya peraturan/tata tertib kelas.

Pemberian pujian/penguatan merupakan tindakan atau respon terhadap suatu bentuk perilaku yang dapat mendorong munculnya peningkatan kualitas tingkah laku tersebut di saat yang lain. Pemberian sanksi/hukuman dalam menegakkan disiplin memang perlu. Kadang-kadang guru memberi hukuman mencaci maki, memukul dan sebagainya. Hukuman kadang-kadang kurang efektif dari ganjaran yang perlu diambil. Dalam pemberian sanksi/hukuman kepada siswa, ada prinsipprinsip/gagasan agar pemberian sanksi/hukuman.

Hasil penelitian ini memperhatikan bahwa kemampuan manajeman kelas guru sekolah dasar negeri Kecamatan Bacukiki Kota Parepare berada pada kategori sedang. Secara keseluruhan, guru yang memiliki tingkat kemampuan manajemen kelas lebih banyak frekuensi guru yang berada pada kategori sedang sampai pada kategori sangat tinggi dengan yang berada pada kategori sangat rendah sampai kategori rendah.

\section{KESIMPULAN \& SARAN}

Berdasarkan hasil pembahasan yang telah dikemukakan pada bab terdahulu tentang implementasi manajemen kelas dikecamatan Bacukiki Kota Parepare, maka dapat disimpulkan bahwa:

1. Gambaran implementasi manajemen kelas di sekolah dasar negeri kecamatan Bacukiki Kota Parepare berada pada kategori sedang. Hal ini berdasarkan pada rekapitulasi implementasi manajemen kelas yang menunjukkan bahwa persentase kategori sedang. Hal ini berarti bahwa guru dalam kegiatan belajar mengajar dalam hal penataan ruang kelas, interaksi guru-siswa, pengaturan waktu pembelajaran, pengaturan sumber belajar, tata tertib, pemberian pujian dan pemberian sanksi melalui peringatan/hukuman belum optimal.

2. Hambatan-hambatan yang dialami guru dalam mengimplementasi manajemen kelas di sekolah dasar negeri kecamatan bacukiki kota parepare berdasarkan hasil observasi 
dan wawancara pada umumnya disebabkan oleh fasilitas yang sangat minim seperti peralatan KIT IPA, IPS, Peta dan buku paket.

\section{Saran}

Berdasarkan hasil penelitian dan kesimpulan yang dikemukakan dalam penelitian ini, maka disarankan beberapa hal sebagai berikut:

1. Kepada para guru di sekolah dasar negeri kecamatan bacukiki kota Parepare dalam penerapan manajemen kelas seyogianya dalam melaksanakan proses belajar mengajar di kelas memperhatikan penataan sumber belajar dan pengaturan kesiswaan.

2. Kepada kepala sekolah, melalui fungsi kepemimpinannya agar mengawasi guru dalam melaksanakan tugasnya termasuk dalam manajemen kelas yang dilakukan oleh guru dalam bentuk supervisi.

3. Kepada pihak yang berkompeten menyiapkan fasilitas agar memperhatikan hal tersebut seperti meja, kursi dan lemari.

\section{DAFTAR PUSTAKA}

Danim, Sudarwan. 2002. Menjadi Peneliti Kualitatif. Bandung: Pustaka Setia.

Fathurrohman. 2007. Strategi BelajarMengajar: Strategi Mewujudkan Pembelajaran Melalui Penanaman Konsep Umum \& Konsep Islam. Bandung: PT.Refika Aditama.

M. Entang dan Raka Joni. 1983. Pengelolaan Kelas. Jakarta: Proyek Pengembangan Pendidikan Tenaga Kependidikan.

Sardiman. 2005. Interaksi dan Motivasi Belajar Mengajar. Bandung: Rajawali Pers.

Sumanto (1990). Metodologi Penelitian Sosial dan Pendidikan. Yogyakarta: Andi Offset 